\title{
ANALISIS PENERAPAN CORPORATE SOCIAL RESPONSIBILITY (CSR) TERHADAP PROFITABILITAS PERUSAHAAN (STUDI KASUS PADA PT SEMEN GRESIK)
}

\author{
Ita noviana 1 \\ Ika listyawati 2 \\ ita.noviana@unaki.ac.id \\ Ika.listyawati@unaki.ac.id \\ Universitas Aki Semarang \\ Riwayat Artikel: dikirim Oktober 2018, diterima September 2018, diterbitkan September 2018
}

\begin{abstract}
The purpose of this study was to determine the company's ability to generate profits before disclosing the Corporate Social Responsibility (CSR) report and after disclosing Corporate Social Responsibility (CSR) at PT Semen Gresik. This study uses Return On Assets as a measure of profitability ratios. The sample uses PT Semen Gresikfinancial statements before Corporate Social Responciability (CSR) in 2003-2006 and after Corporate Social Responciability (CSR) in 2009-2012. The data collection method used in this study is secondary data, obtained from PROPER and from the company's official website. Data analysis method using descriptive statistical tests, Based on the results of testing descriptive statistics there is an increase in profitability after the Corporate Social Responciability (CSR) or Sustainability report.
\end{abstract}

Keywords: Corporate Social Responsibility(CSR), Profitability, Return On Assets (ROA). 


\section{PENDAHULUAN}

\section{Latar Belakang Masalah}

Sebuah perusahaan bisa dikatakan besar dan berkembang dapat diamati dari laporan keuangan aktivitas operasi perusahaan, yang nilai asset dan liabilitasnya meningkat dari waktu ke waktu. Dampak perkembangan ini pastinya diikuti oleh pembagian dividen yang semakin besar pula dan membuat para investor untuk bertahan dan meningkatkan investasinya dalam perusahaan tersebut. Namun, perusahaan yang perkembangannya besar saja tidak cukup untuk dapat tetap eksis di era globalisasi ini, jika tidak diikuti oleh laporan pertanggungjawaban sosial dan lingkungannya. Karena ini akan berdampak pada image yang baik untuk perusahaan, dan dampaknya, mendapatkan konsumen yang lebih banyak, lebih loyal, dan pada akhirnya akan meningkatkan keuntungan perusahaan. (Sari, 2014). Tanggung jawab sosial dan lingkungan oleh perusahaan ini bisa diwujudkan melalui progam Corporate Social Responsibility (CSR) dan dilaporkannya pada laporan keberlanjutan (sustainability report). Seperti yang terdapat dalam undangundang nomor 40 tahun 2007 tentang Perseroan Terbatas, mengharuskan perusahaan memperhatikan dan memenuhi tanggung jawab sosial dan lingkungan. Sebagian besar perusahaan dari berbagai sektor bisnis di Indonesia mengklaim bahwa perusahaan mereka telah melaksanakan kewajiban sosialnya terhadap lingkungan sekitar, hal ini berarti bahwa sebagian besar perusahaan telah melakukan pengungkapan Corporate Sosial Responsibility sebagai motivasi untuk meningkatkan kepercayaaan publik terhadap pencapaian perbaikan lingkungan sekitar perusahaan. (Nur \& Priantinah, 2012).
Corporate social responsibility (Hackston dan Milne, 1996) merupakan proses pengkomunikasian dampak sosial dan lingkungan dari kegiatan ekonomi organisasi terhadap kelompok khusus yang berkepentingan dan terhadap masyarakat secara keseluruhan. Informasi yang diungkapkan dalam laporan tahunan dapat dikelompokkan menjadi dua yaitu pengungkapan wajib (mandatory disclosure) dan pengungkapan sukarela (voluntary disclosure). (Hadi, 2010)

Profitabilitas suatu perusahaan menunjukan kemampuan suatu perusahaan dalam menghasilkan laba selama periode tertentu pada tingkat penjualan, aset dan modal saham tertentu. Profitabilitas menjadi suatu pertimbangan yang sangat penting untuk investor memutuskan keputusan investasinya. Profitabilitas dapat kita ukur dengan menggunakan rasio keuangan sebagai salah satu alat untuk menganalisis kemampuan perusahaan menghasilkan keuntungan. (Rita, 2012)

PT Semen Indonesia (Persero) Tbk, yang sebelumnya bernama PT Semen Gresik (Persero) Tbk merupakan Badan Usaha Milik Negara (BUMN) yang bergerak di bidang industri bahan bangunan. Perseroan berperan sebagai Strategic Holding Company dengan berbagai lini usaha yang menawarkan solusi lengkap dalam pembangunan. PT Semen Gresik ini didirikan pada tanggal 7 Agustus 1957 oleh Ir Soekarno Presiden pertama Republik Indonesia. Dalam perkembangannya, Perseroan melakukan akuisisi dua perusahaan BUMN lain, PT Semen Padang (Persero) dan PT Semen Tonasa (Persero) dan pada tahun 2012 Perseroan melakukan langkah korporasi dengan mengakuisisi Thang Long Cement Company (TLCC) Vietnam. Pada tanggal 7 Januari 2013 Perseroan bertransformasi menjadi PT Semen Indonesia (Persero) Tbk. 
Di beberapa tahun yang lalu PT Semen Gresik telah meraih peringkat hijau di PROPER (Progam kinerja Perusahaan). PROPER adalah progam dari Kementerian Lingkungan hidup yang merupakan salah satu upaya untuk mendorong penaatan perusahaan dalam pengelolaan lingkungan hidup melalui instrumen informasi, hal ini dilakukan melalui berbagai kegiatan yang diarahkan untuk: (1) mendorong perusahaan untuk menaati peraturan perundang-undangan melalui insentif dan disinsentif reputasi, dan (2) mendorong perusahaan yang sudah baik kinerja lingkungannya untuk menerapkan produksi bersih (cleaner production) dan peraturan ini telah di tetapkan dalam Undang-Undang Republik Indonesia Nomor 32 Tahun 2009 Tentang Perlindungan Dan Pengelolaan Lingkungan Hidup. Adanya progam pengahargaan tersebut, perusahaan diharuskan lebih memperhatikan dampak lingkungan dan sosialnya. Macam-macam kategori dalam PROPER ini terbagi menjadi 5 macam, yaitu Emas, Hijau, Biru, Merah dan Hitam. Tingkatan yang paling atas adalah PROPER Emas, dimana sebuah perusahaan tersebut bukan hanya melakukan progam lingkungan saja tetapi melakukan pengembangan upaya masyarakat secara berkesinambungan. Sedangkan tingkatan yang paling rendah adalah PROPER Hitam, peringkat ini menunjukkan bahwa perusahaan belum melakukan upaya dalam pengelolaan lingkungan sebagaimana yang dipersyaratkan sehingga berpotensi mencemari lingkungan, dan beresiko untuk ditutup ijin usahanya oleh Kementerian Lingkungan Hidup.

Dari uraian diatas penulis ingin mengetahui pengaruh Corporate Social Responsibility (CSR) terhadap profitabilitas. Maka penulis melakukan penilitian ini dengan judul: "Analisis Penerapan Corporate Social Responsibility (CSR) Terhadap Profitabilitas Perusahaan Studi pada PT Semen Gresik".

\section{Rumusan Masalah}

Berdasarkan uraian latar belakang di atas, maka rumusan masalah dalam penelitian ini adalah "Apakah terdapat perbedaan profitabilitas sebelum dengan sesudah menerapkan Corporate Social Responsibility (CSR)"?

\section{Tujuan Penelitian}

Berdasarkan masalah yang telah diuraikan, maka tujuan penelitian adalah mengetahui bagaimana kemampuan perusahaan dalam menghasilkan laba (profitabilitas) sebelum menerapkan Corporate Social Responsibility (CSR) dengan sesudah menerapkan Corporate Social Responsibility (CSR) pada PT Semen Gresik.

\section{Ruang Lingkup}

Penelitian ini menghubungkan analisis kinerja keuangan pada suatu perusahaan sebelum adanya pengungkapan CSR dan setalah terjadinya pengungkapan CSR. Pada penelitian ini kinerja keuangan diproksikan oleh Return on Assets (ROA), alasannya adalah karena keberhasilan pemimpin sebagai pengelola perusahaan dapat dilihat dari kinerja keuangan yang ditunjukkan oleh jumlah penjualan, tenaga kerja, asset yang dimiliki dan analisis rasio yang disajikan dalam laporan keuangan (Widaryanti 2007). Adapun rasio yang digunakan adalah rasio profitabilitas (Return On Asset /ROA). Karena rasio ini dipandang cukup representatif dalam mencerminkan kinerja keuangan perusahaan. Sedangkan pengungkapan CSR direpresentasikan oleh adanya dari laporan keberlanjutan atau sustainability report.

\section{KAJIAN TEORITIS}

\section{Telaah Pustaka}

Stakeholder theory dan legitimacy theory merupakan teori yang mendasari penelitian di bidang tanggung jawab sosial 
perusahaan. Teori stakeholder erat kaitannya dengan teori legitimasi (Deegan, 2004). Kedua teori ini menjelaskan alasan pengungkapan suatu informasi oleh perusahaan dalam laporan keuangan.

\section{Hubungan Stakeholder theory dengan Corporate Social Responcibility (CSR)}

Teori stakeholder pada awalnya muncul didasari oleh perkembangan kesadaran dan pemahaman bahwa perusahaan memiliki stakaholder yaitu pihak-pihak yang berkepentingan dalam perusahaan, hal inilah yang menjadikan banyak literatur manajemen baik akademis maupun profesional membahasnya. Studi pertama yang dikemukakan mengenai stakeholder adalah Strategic Management : A Stakeholder Approach oleh Freeman (1984).

Stekholder theory dimulai dengan asumsi bahwa nilai secara eksplisit dan merupakan bagian dari kegiatan usaha (Freeman dkk, 2004). Bentuk dari kebijakan dan praktik perusahaan terhadap pemangku kepentingan pemegang saham (stakholder) ini adalah memperhatian dan memenuhi kebutuhan serta kepentingan stakeholder di atas kepentingan lainnya, karena peran serta kedudukan stakeholder sangat penting bagi kelangsungan hidup perusahaan atau perkembangan perusahaan secara berkesinambungan. Bagian dari kepentingan stakeholder utamanya masyarakat adalah perusaahaan memberikan respon timbal balik terhadap tanggung jawab sosial dan lingkungan melalui pelaksanaan progam corporate social responsibility (CSR).

\section{Hubungan Teori Legitimasi dengan Corporate Social Responcibility (CSR)}

Legitimasi merupakan keberpihakan orang dan kelompok orang yang sangat peka terhadap gejala lingkungan sekitarnya baik fisik maupun non fisik.
Hal ini menjadi gambaran bahwa teori legitimasi memiliki keterkaitan hubungan anatara pihak eksternal (masyarakat) dengan pihak internal (perusahaan). Bila dilihat lebih mendalam, keterlibatan masyarakat dengan perusahaan tersebut adalah kegiatan tanggung jawab sosial dan lingkungan Corporat Social Responsibility (CSR). (Hadi, 2010)

\section{Gambaran perusahaan}

PT Semen Gresik (Persero) Tbk yang sekarang menjadi PT Semen Indonesia (Persero) Tbk merupakan Badan Usaha Milik Negara (BUMN) yang bergerak di bidang industri bahan bangunan dan berperan sebagai Strategic Holding Company menawarkan solusi lengkap dalam pembangunan. Pada tanggal 7 Agustus 1957, Ir Soekarno (Presiden pertama Republik Indonesia) meresmikan dan-menjadikan Perseroan ini sebagai penopang pembangunan Indonesia.

$$
\text { Pada tahun 1991, Perseroan }
$$
mencatatkan diri sebagai perusahaan BUMN pertama yang Go Public di Bursa Efek Surabaya dan Bursa Efek Jakarta (Bursa Efek Indonesia), dengan kode emiten SMGR. Dalam perkembangannya, Perseroan mengakuisisi dua perusahaan BUMN lain, PT Semen Padang (Persero) dan PT/Semen Tonasa (Persero) dan menjadi perusahaan persemenan terbesar di Indonesia. Seiring dengan visi perusahaan, tahun 2012 Perseroan melakukan langkah korporasi dengan mengakuisisi Thang Long Cement Company (TLCC) Vietnam. Tanggal 7 Januari 2013 Perseroan bertransformasi menjadi PT Semen Indonesia (Persero) Tbk, yang saat ini memiliki 14 Integrated Cement Plant yang tersebar di berbagai daerah antara lain di Kabupaten Indarung Sumatera Barat, di Tuban Jawa Timur, di Pangkep Sulawesi Selatan, di Rembang Jawa Tengah dan di Quang Ninh Vietnam dengan total kapasitas terpasang sebesar 31,8 juta Ton semen per tahun. 
Distribusi dan pemasaran PT Semen Indonesia mempunyai 3 Grinding Plant, 26 Packing Plant, 11 pelabuhan khusus, 17 gudang penyangga, 651 distributor di merek semen yang ternama yaitu Semen Padang, Semen Gresik dan Semen Tonasa. PT Semen Indonesia mempunyai tiga prinsip yaitu "Untuk Kualitas • Untuk Bumi • Untuk Indonesia”.

\section{Corporate Social Responcibility \\ Pengertian Corporate Social Responcibility \\ Pada tahun 1979 Archie B.} Caroll (Professor at the University of Georgia) mengenalkan teori the 'FourPart Model of Corporate Social Responsibility'. Teori yang dibangun oleh Caroll tersebut meyakini CSR sebagai konsep multi-lapis, yang dapat dibedakan menjadi empat aspek (yang saling berhubungan) yaitu tanggung jawab filantropi, etis, hukum dan ekonomi. Keempat aspek tanggungjawab tersebut diilustrasikan dalam sebuah piramida yang masing-masing tanggung jawab berada dalam sebuah lapisan yang berurutan.

\section{Dalam perspektif teoritik}

CSR, Archie B. Caroll (Professor at the University of Georgia) memperkenalkan teori the 'Four-Part Model of Corporate Social Responsibility'. Teori yang dibangun oleh Caroll tersebut meyakini CSR sebagai konsep multi-lapis, yang dapat dibedakan menjadi empat aspek (yang saling berhubungan) yakni tanggung jawab filantropi, etis, hukum dan ekonomi. Keempat aspek tanggungjawab tersebut diilustrasikan dalam sebuah piramida yang masingmasing tanggung jawab berada dalam sebuah lapisan yang berurutan. Teori yang disampaikan oleh Caroll tersebut merupakan dasar justifikasi teoritik bagi keberadaan CSR. Konsepsi CSR yang diberikan oleh Caroll adalah yang paling lama bertahan dan sering menjadi rujukan dari sekian banyaknya konsepsi CSR yang ada. seluruh penjuru Nusantara, dan 78 distributor yang tersebar di Vietnam. Di Indonesia, Perseroan memiliki 3

\section{Prinsip-prinsip Corporate Social Responsibility \\ Menurut Crowther David (2008) membagi prinsip-prinsip CSR menjadi tiga macam yaitu, sustainability, accountability dan tranparency.}

1) Sustainability, berkaitan dengan bagaimana perusahaan dalam melakukan aktivitasnya (action) tetap memperhitungkan keberlanjutan sumberdaya dimasa depan. Keberlanjutan mengarahkan bagiamana penggunaan sumberdaya sekarang tetap memperhatikan dan memperhitungkan kemampuan generasi masa depan.

2) Accountability, adalah upaya perusahaan terbuka dan bertanggungjawab atas aktivitas yang telah dilakukan. Akuntabilitas diburuhkan kerika aktivitas perusahaan mempengaruhi dan dipengaruhi lingkungan eksternal. Konsep ini menjelaskan pengaruh kuantitatif aktivitas perusahaan terhadap pihak internal dan eksternal. 3) Transparancy, merupakan prinsip penting bagi pihak eksternal. Transparansi ini berkaitan dengan pelaporan aktivitas perusahaan, karena berperan untuk mengurangi asimetri informasi, kesalahpahaman, khususnya informasi dan pertanggungjawaban berbagai dampak dari lingkungan.

\section{Profitabilitas}

Profitabilitas merupakan salah satu pengukuran kinerja perusahaan. Profitabilitas suatu perusahaan menunjukan kemampuan suatu perusahaan dalam menghasilkan laba selama periode tertentu pada tingkat penjualan, aset dan modal saham tertentu. Return On Equity (ROE) atau profitabilitas adalah pengukuran dari 
penghasilan atau income yang tersedia bagi

pemilik perusahaan atas modal yang mereka investasikan di dalam perusahaan. (Rohmah, 2015)

Committee on terminology mendefinisikan profitabilitas adalah jumlah yang berasal dari pengurangan harga pokok produksi, biaya lain dan kerugian dari penghasilan atau penghasilan operasi. Sedangkan menurut APB Statement mengartikan

\section{Pengukuran Rasio Profitabilitas}

Rasio profitabilitas terdiri dari dua jenis, yaitu rasio yang menunjukkan profitabilitas dalam kaitannya dengan penjualan dan rasio yang menunjukan profitabilitas dalam kaitannya dengan investasi. Profitabilitas dalam kaitannya dengan penjualan terdiri dari atas Marjin Profitabilitas Investasi profitabilitas adalah kelebihan (defisit) penghasilan diatas biaya selama satu periode akuntansi (Harahap, 2008). Profitabilitas adalah ukuran pokok keseluruhan keberhasilan suatu perusahaan (Simamora, 2000). Dari beberapa pengertian tersebut dapat disimpulkan bahwa profitabilitas adalah penghasilan yang diinginkan oleh perusahaan dalam menjual produknya pada periode akuntansi tertentu.
Return On Equity (ROE) atau Tingkat Pengembalian atas Ekuitas. Return On Equity merupakan perbandingan antara laba bersih sesudah pajak dengan total ekuitas. Return On Equity merupakan suatu pengukuran dari penghasilan (income) yang tersedia bagi para pemilik perusahaan (baik pemegang saham biasa maupun pemegang saham preferen) atas modal yang mereka investasikan di dalam perusahaan
Laba Kotor (Gross Profit Margin) dan Marjin Laba Bersih (Net Profit Margin). Profitabilitas dalam kaitannya dengan investasi terdiri dari Tingkat Pengembalian Aset (ROA) dan Tingkat Pengembalian Ekuitas (ROE).

\section{Return On Equity $(\mathrm{ROE})=\underline{\text { Laba bersih setelah pajak }}$}

Total Ekuitas

Return On Asset (ROA) yaitu rasio antara Net Income After Tax terhadap aset secara keseluruhan menunjukan ukuran produktivitas aktiva dalam memberikan pengembalian pada penanaman modal (Sawir, 2009). Rasio ini merupakan ukuran jika seseorang ingin mengevaluasi seberapa baik ANALISIS PENERAPAN CORPORATE SOCIAL RESPONSIBILITY (CSR)...
(Syafri, 2008). Return On Equity adalah rasio yang memperlihatkan sejauh manakah perusahaan mengelola modal sendiri (net worth) secara efektif, mengukur tingkat keuntungan dari investasi yang telah dilakukan pemilik modal sendiri atau pemegang saham perusahaan (Sawir, 2009). ROE menunjukkan rentabilitas modal sendiri atau yang sering disebut rentabilitas usaha. Return On Equity dihitung dengan rumus: perusahaan telah memakai dananya, tanpa memperhatikan besarnya relatif sumber dana tersebut dengan mengukur berapa presentase laba bersih sesudah pajak terhadap total aset perusahaan tersebut. Return on Asset dapat dihitung dengan rumus: 


\section{Return on Asset $(\mathrm{ROA})=\underline{\text { Laba bersih setelah pajak }}$}

Total asset

\section{Hubungan Corporate Social Responsibility (CSR) dan Profitabilitas}

Riset penelitian empiris terhadap hubungan pengungkapan sosial perusahaan, profitabilitas menghasilkan hasil yang sangat beragam. Penelitian yang dilakukan Hackston and Milne (1996) melaporkan bahwa profitabilitas tidak berpengaruh terhadap pengungkapan tanggung jawab sosial perusahaan. Yuliani (2003) menunjukan hasil bahwa profitabilitas tidak berpengaruh terhadap pengungkapan sosial dan lingkungan perusahaan. Cahya, Adi Bramantya (2010) menunjukkan hasil bahwa kinerja keuangan yang terdiri dari rasio Size, ROA, dan Leverage berpengaruh secara simultan terhadap Corporate Social
Responsibility (CSR) perbankan di Indonesia periode 2007-2008.

Haryani (2011) hasil penelitian menunjukan bahwa perusahaan PT Unilever Indonesia Tbk setelah menerapkan Corporate Social Resposibility (CSR) lebih mampu memanfaatkan kekayaannya untuk menghasilkan laba. Bertentangan dengan teori agensi yang menyatakan bahwa semakin besar perolehan laba yang didapat perusahan, maka semakin luas informasi sosial yang diungkapkan perusahaan. Mengingat akan ketidak konsistenan dari hasil penelitian para ahli yang telah dikemukakan di atas, maka dalam penelitian ini menguji kembali pengaruh Corporate Social Resposibility (CSR) terhadap profitabilitas di PT Semen Gresik Tbk.

\section{METODOLOGI}

\section{Rancangan Penelitian}

Penelitian ini menggunakan rancangan penelitian deskriptif, dengan cara menganalisis data dengan menjelaskan data yang telah terkumpul.
Peneliti menggambarkan tingkat penerapan Corporate Social Responsibility (CSR) dan profitabilitas pada PT Semen Gresik Tbk.

\section{Jenis Penelitian}

Penelitian ini dapat diklasifikasikan ke dalam jenis penelitian kuantitatif, karena penelitian menekankan pada pengujian teori-teori melalui pengukuran Variabel Penelitian

Variabel independen merupakan variabel yang mempengaruhi atau yang menjadi sebab perubahannya atau timbulnya variabel dependen, sedangkan variabel dependen merupakan variabel yang dipengaruhi atau menjadi akibat karena adanya variabel lain (variabel independen). variabel-variabel penelitian dengan angka dan melakukan analisis data statistik.

Variabel independen dalam penelitian ini adalah penerapan Corporate Social Responsibility (CSR), sedangkan variabel dependennya adalah profitabilitas perusahaan.

\section{Sampel Penelitian}

ANALISIS PENERAPAN CORPORATE SOCIAL RESPONSIBILITY (CSR)... 
Perusahaan yang digunakan dalam penelitian ini adalah PT Semen Gresik Tbk. Laporan keuangan yang digunakan sebelum menerapkan CSR tahun 2003-2006 dan sesudah menerapkan CSR tahun 2009-2012.

\section{Metode Pengumpulan data}

Data yang digunakan dalam penelitian ini adalah data sekunder, yaitu data yang diperoleh dari data peringkat PROPER (Progam Kinerja Perusahaan) yaitu dari website Kementerian Lingkungan hidup dan website resmi PT Semen Gresik Tbk (PT Semen Indonesia Tbk) dan juga dari sumber atau literatur yang lain yang berkaitan dengan masalah yang diteliti.

\section{Metode Analisis Data}

\section{Profitabilitas}

Profitabilitas dalam penelitian ini menggunakan Return On Asset.

\section{Uji Statistik Deskriptif}

Statistik dengan analisis deskriptif, yaitu menghasilkan analisa dispersi (minimum, maksimum), dan mean. Dalam penelitian ini analisis deskriptif digunakan untuk mengetahui tingkat penerapan Corporate Social Resposibility (CSR) dan profitabilitas PT Semen Gresik Tbk.

\section{HASIL DAN PEMBAHASAN}

Tabel 1. Laporan Keuangan PT Semen Gresik (Sebelum adanya CSR)

\begin{tabular}{|c|c|c|}
\hline \multirow{2}{*}{ Tahun } & \multicolumn{2}{|c|}{$\begin{array}{c}\text { Laba Bersih Sesudah Pajak } \\
\text { (EAT) }\end{array}$} \\
\cline { 2 - 4 } & $\begin{array}{c}\text { (Dalam Jutaan } \\
\text { Rupiah) }\end{array}$ & \multicolumn{2}{c|}{ (Dalam Jutaan Rupiah) } \\
\hline 2003 & 15.987 .821 & Sebelum CSR \\
\hline 2004 & 18.831 .000 & 716.787 \\
\hline 2005 & 19.873 .156 & 761.991 \\
\hline 2006 & 20.513 .543 & 848.699 \\
\hline
\end{tabular}

Sumber: Laporan keuangan PT Semen Gresik Tbk (tahun 2003-2004)

Tabel 2. Laporan Keuangan PT Semen Gresik Tbk Tahun 2008-2012 (Sesudah adanya CSR) 


\begin{tabular}{|c|c|c|}
\hline \multirow{2}{*}{ Tahun } & Total Asset & $\begin{array}{c}\text { Laba Bersih Sesudah Pajak } \\
\text { (EAT) }\end{array}$ \\
\cline { 2 - 3 } & $\begin{array}{c}\text { (Dalam Jutaan } \\
\text { Rupiah) }\end{array}$ & (Dalam Jutaan Rupiah) \\
\hline \multicolumn{2}{|c|}{ Sesudah CSR } \\
\hline 2009 & 12.951 .308 & $3,326.000$ \\
\hline 2010 & 15.562 .999 & $3,634.000$ \\
\hline 2011 & 19.661 .603 & $3,925.000$ \\
\hline 2012 & 26.579 .084 & $4,847.000$ \\
\hline
\end{tabular}

Sumber: Laporan keuangan PT Semen Gresik Tbk (tahun 2009-2012)

Tabel 3. Profitabilitas Sebelum Menerapkan Corporate Social Responsibility

(CSR) Tahun 2003-2006

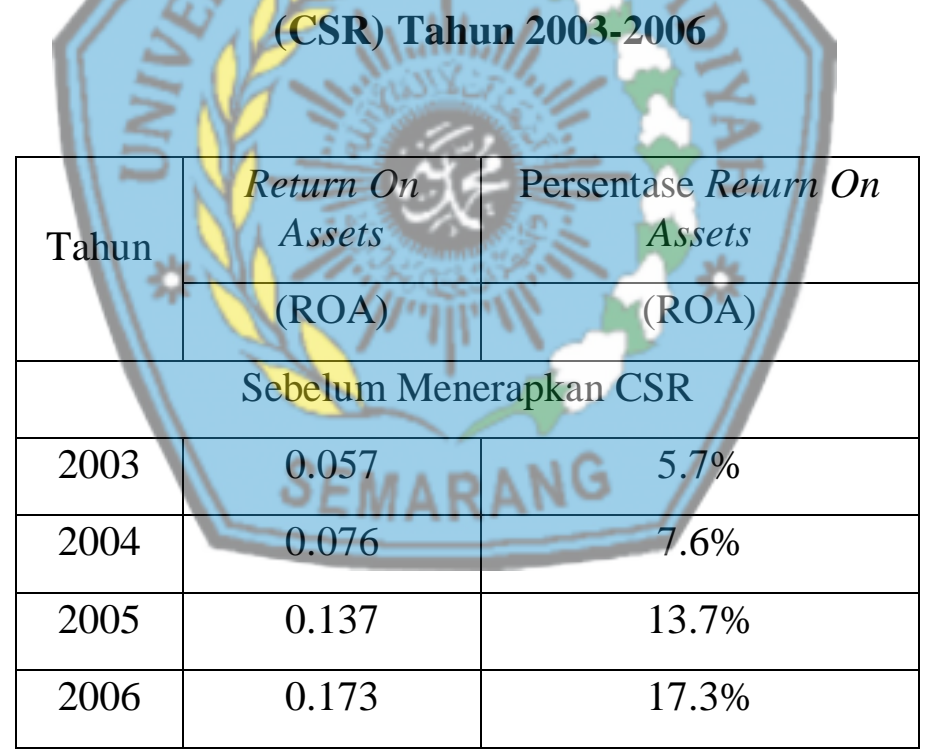

Sumber: Data Diolah

Dari tabel 3 tersebut dapat dilihat, profitabilitas untuk tahun 2003 adalah sebesar $0,057 \quad(5,7 \%)$. Menunjukkan kemampuan perusahaan menghasilkan laba dari aset yang dipergunakan, artinya dengan menggunakan Rp 1.000 aset akan menghasilkan laba bersih sesudah pajak sebesar Rp 57. Tahun 2004 adalah sebesar $0,076 \quad(7,6 \%)$. Menunjukkan kemampuan perusahaan menghasilkan laba dari aset yang dipergunakan, artinya dengan menggunakan Rp 1.000 aset akan menghasilkan laba bersih sesudah pajak sebesar Rp 76. Tahun 2005 adalah sebesar 0,137 (13,7\%). Menunjukkan kemampuan perusahaan menghasilkan laba dari aset yang dipergunakan, artinya dengan menggunakan $\mathrm{Rp}$ 1.000 aset akan menghasilkan laba bersih sesudah pajak sebesar Rp 137. ANALISIS PENERAPAN CORPORATE SOCIAL RESPONSIBILITY (CSR)... 
Tahun 2006 adalah sebesar 0,173 $(17,3 \%)$. Menunjukkan kemampuan perusahaan menghasilkan laba dari aset yang dipergunakan, artinya dengan menggunakan $\mathrm{Rp} 1.000$ aset akan menghasilkan laba bersih sesudah pajak sebesar Rp 173.

\section{Tabel 4. Profitabilitas Sesudah Menerapkan Corporate Social Responsibility} (CSR) Tahun 2002-2017

\begin{tabular}{|c|c|c|}
\hline \multirow{2}{*}{ Tahun } & $\begin{array}{c}\text { Return On } \\
\text { Assets }\end{array}$ & $\begin{array}{c}\text { Persentase Return On } \\
\text { Assets }\end{array}$ \\
\cline { 2 - 3 } & (ROA) & (ROA) \\
\hline \multicolumn{3}{|c|}{ Setelah Menerapkan CSR } \\
\hline 2009 & 0,257 & $25,7 \%$ \\
\hline 2010 & 0,233 & $23,3 \%$ \\
\hline 2011 & 0,199 & $19,9 \%$ \\
\hline 2012 & 0,182 & $18,2 \%$ \\
\hline
\end{tabular}

\section{Sumber: Data diolah}

Dari tabel 4 tersebut dapat dilihat, profitabilitas untuk tahun 2009 adalah sebesar 0,257 (25,7\%). Menunjukkan kemampuan perusahaan menghasilkan laba dari aset yang dipergunakan, artinya dengan menggunakan Rp 1.000 aset akan menghasilkan laba bersih sesudah pajak sebesar Rp 257. Tahun 2010 adalah sebesar 0,233 (23,3\%). Menunjukkan kemampuan perusahaan menghasilkan laba dari aset yang dipergunakan, artinya dengan menggunakan $\mathrm{Rp} 1.000$ aset akan menghasilkan laba bersih sesudah pajak sebesar Rp 233. Tahun 2011 adalah sebesar 0,199 (19,9\%). Menunjukkan kemampuan perusahaan menghasilkan laba dari aset yang dipergunakan, artinya dengan menggunakan $\mathrm{Rp} 1.000$ aset akan menghasilkan laba bersih sesudah pajak sebesar Rp 199. Tahun 2012 adalah sebesar $0,182 \quad(18,2 \%)$. Menunjukkan kemampuan perusahaan

\section{Analisis Penerapan Corporate Sosial Responsibility (CSR) Terhadap Profitabilitas PT Semen Gresik Tbk}

Pengukuran statistik deskriptif digunakan untuk menghitung rata-rata (mean) profitabilitas sebelum dan sesudah menerapkan CSR. Variabel yang digunakan adalah rasio profitabilitas menggunakan ROA (Return on Assets). 
Tabel 5. Statistik Deskriptif Sebelum dan Sesudah menerapkan CSR

\begin{tabular}{|c|c|c|c|c|}
\hline & $\mathrm{N}$ & $\mathrm{ROA}$ & $\mathrm{ROA}$ & \multirow{2}{*}{ Mean } \\
\cline { 3 - 4 } & & Minimum & Maximum & \\
\hline Profitabilitas & 4 & 0.057 & 0.173 & 0.1107 \\
Sebelum CSR & & & & \\
\hline Profitabilitas & 4 & 0.182 & 0.257 & 0.2177 \\
Setelah CSR & & & & \\
\hline
\end{tabular}

Sumber: Data diolah

Pada tabel 5 di atas, hasil dari statistik deskriptif menunjukkan bahwa profitabilitas PT Semen Gresik Tbk sesudah menerapkan CSR lebih profitable dibandingkan dengan sebelum menerapkan CSR. Hal ini menunjukkan bahwa sesudah menerapkan CSR PT Semen Gresik Tbk lebih mampu memanfaatkan seluruh asetnya untuk menghasilkan laba diband ingkan dengan sebelum menerapkan CSR.

Dapat dilihat bahwa rata-rata sebelum hingga sesudah menerapkan CSR mengalami peningkatan, sebelum menerapkan CSR sebesar 0,1107 dan sesudah menerapkan CSR sebesar

0,2177. Rata-rata profitabilitas mengalami peningkatan sesudah menerapkan CSR sebesar 0,2024. Dengan minimum yang menunjukan nilai terendah dari suatu deretan data, untuk profitabilitas sebelum CSR adalah 0,057 dan sesudah adalah 0,182. Maximum menunjukkan nilai tertinggi dari suatu deretan data untuk profitabilitas sebelum CSR adalah 0,173 dan sesudah CSR adalah 0,257. Berdasarkan hasil statistik deskriptif dapat dilihat secara keseluruhan menggalami peningkatan. Nilai minimum, maximum, dan mean terdapat peningkatan sesudah menerapkan Corporate Social Resposibility (CSR).

\section{Kesimpulan}

$\begin{array}{lll}\text { Berdasarkan hasil analisis } & \text { dari hasil penelitian yang telah dilakukan } \\ \text { mengenai pengaruh penerapan CSR } & \text { bahwa terdapat perbedaan profitabilitas } \\ \text { terhadap profitabilitas perusahaan maka } & \text { sebelum dan sesudah menerapkan CSR, } \\ \text { dapat disimpulan yaitu sebagai berikut: } & \text { melaului uji statistik nilai minimum, } \\ \text { Corporate Social Responsibility (CSR) } & \text { maximum, dan mean terdapat } \\ \text { memberikan pengaruh terhadap } & \text { peningkatan sesudah menerapkan } \\ \text { peningkatan profitabilitas pada PT } & \text { Corporate Social Responsibility (CSR). }\end{array}$

Semen Gresik Tbk, hal ini dapat dilihat

\section{Saran}

Adapun saran-saran yang dapat penulis berikan dalam penelitian ini adalah

\section{Bagi Perusahaan:}

Berdasarkan hasil penelitian bahwa penerapan Corporate Social Responsibility (CSR) dapat meningkatkan

profitabilitas perusahaan, disarankan agar perlunya meningkatkan intensitas program CSR dimaksudkan untuk dapat 
meningkatkan citra PT Semen Gresik Tbk di mata masyarakat sehingga akan mempengaruhi kinerja keuangan di masa yang akan datang.

\section{Bagi Penelitian Selanjutnya:}

Untuk penelitian selanjutnya dapat menambahkan variabel, memperpanjang

\section{DAFTAR PUSTAKA}

Carroll, Archie B. 2004. Managing Ethically with Global Stakeholders: A Present and Future Challenge. Academy of Management Executive, Vol. 18, No. 2 (114-120)

Harahap, Sofyan Syafri. 2008, Analisis Kritis Laporan Keuangan,

Crowther, David andGuler Aras. 2008. Corporate Social Responsibility 1st Edition. Di akses pada 3 Maret 2017

Freeman, R. E. 1984. Strategic Management: $\quad A$ Stakeholder Approach, Boston, Pitman.

Sydney. http://proper.menlh.go.id.

Diakses tanggal 20 Februari 2019

Deegan, C. 2004. "Financial Accounting Theory". Mcgraw-Hill Book Company,

\section{5}

Haryai, Implementasi Corporate Social Responsibility (CSR) Terhadap Profitabilitas Perusahaan, Universitas Budi Luhur.

periode atau rentang waktu atau mengubah obyek yang diteliti, sehingga lebih diketahui faktor-faktor yang berpengaruh dengan adanya Corporate Social Responsibility (CSR) pada perusahaan PT Semen Gresik Tbk maupun pada perusahaan lain.

Hadi, N. (2010). Corporate Social Responsibility. Jakarta: Graha Ilmu.

Hanafi, Mamduh M. dan Abdul Halim. 2009. Analisa Laporan Keuangan. Edisi Keempat. CetakanPertama. Yogyakarta: UPP STIM YKPN. Jakarta: Raja Grafindo Persada

Hasibuan,Muhammad Rizal. 2001. Pengaruh Karakteristik Perusahaan Terhadap Pengungkapan Sosial (Social Disclosure) Dalam Laporan Tahunan Emiten di BEJ dan BES, Tesis S2 Magister Akuntansi.

Guidance On Social Responsibility, Document ISO 26000, 2008.

Hackston, D. and M. J. Milne. 1996, Some Determinants of Social and Environmental Disclosures in New Zealand Companies, Accounting, Auditing and Accountability Journal, Vol. 9 N0. 1:77108.
Henry, Simamora. 2000, Akuntansi Basis Pengambilan Keputusan Bisnis, Jakarta: Salemba Empat.

http://www.semengresik.com/download/ . Diakses tanggal 01 Januari 2019 
https://semenindonesia.com/sustainability -archive/?lang=en.

Diakses tanggal 01 Januari 2019

Mathews, M.R. 1995. Social and Environment al Accounting: A Practical Demonstration of Ethical Concern. Journal of Business Ethics, 14(8), pp: 663671.

Munawir, S. 2002. Akuntansi Keuangan dan Manajemen, Edisi Pertama, Cetakan I, Yogyakarta: BPFE.
Sari, N. (2014). Analisis Pengungkapan Corporate Social Responcibility Berdasarkan Global Reporting Initiatives (GRI): Studi Kasus Perusahaan Tambang Batubara Bukit Asam (Persero) Tbk dan Timah (Persero) Tbk . Jurnal Binus Business Review, 527-536.

Sawir, Angnes. 2001, Analisa Kinerja Keuangan dan Perencanaan Keuangan Perusahaan, Jakarta: Gramedia Pustaka Utama.

Syafari Harahap, Sofyan. 2008, Analisa Kritis Atas Laporan Keuangan, Jakarta: Raja Grafindo Persada.

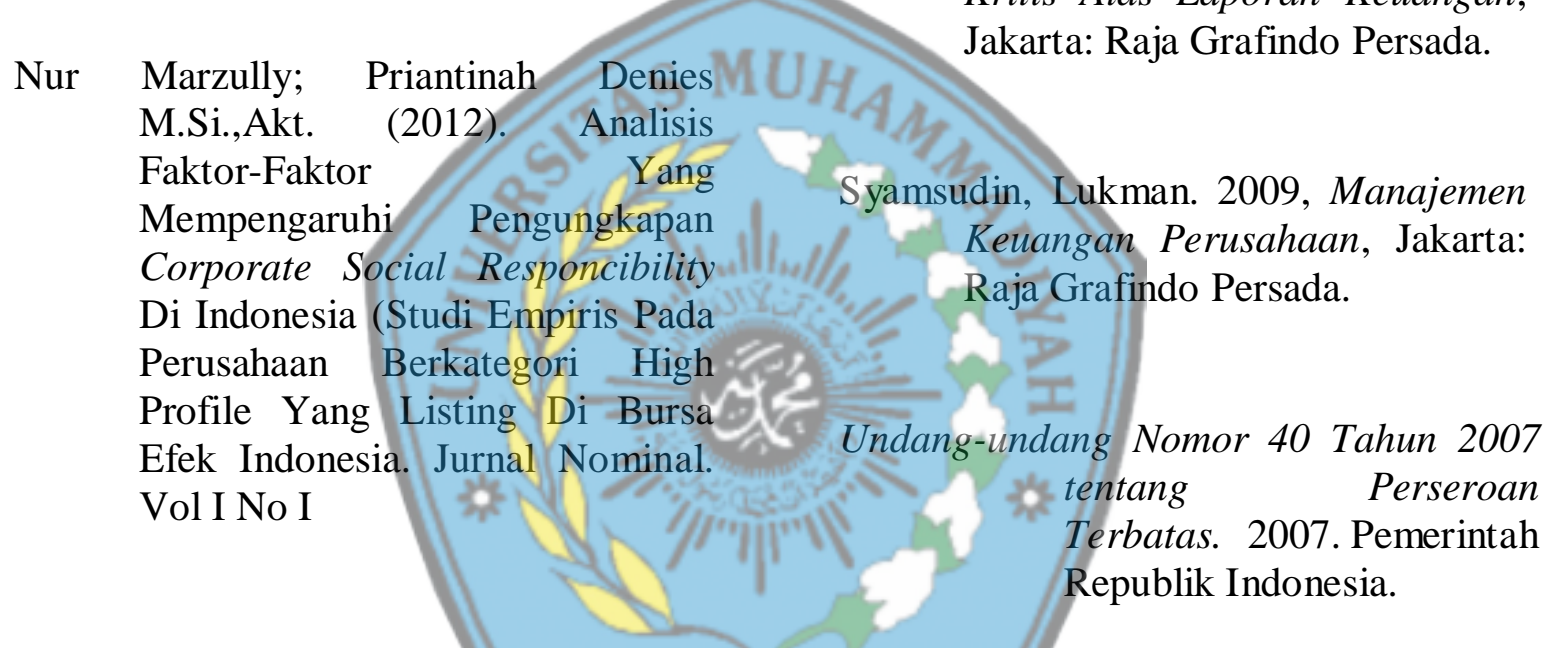

Rita, Y. S. (2012). Perbandingan ARA Widaryanti.2007.”Analisis Pengaruh Profitabilitas Perusahaan Sebelum Pengungkapan Tanggunga Jawab dan Setelah Penerapan UU No. 40/2007 Tentang Kewajiban Sosial Terhadap Perusahaan”. Perseroan Terbatas (Studi Empiris pada Perusahaan-Perusahaan yang Bergerak di Bidang Energi dan Sumber Daya Mineral). Jurnal Riset Manajemen Sains Indonesia (JRMSI) Vol. 3 No. 1.

Yuliani, Rahma. 2003, Pengaruh Karakteristik Perusahaan Terhadap Praktek Pengungkapan Sosial dan Lingkungan di

Rohmah, fauziyatur (2015). Analisis Penerapan Corporate Social Responcibility (CSR) Terhadap Profitabilitas Perusahaan (Studi Kasus pada PT Sampoerna Tbk). Indonesia, Tesis S2 Magister Akuntansi.

Zuhroh, Diana dan I Putu Pande Heri Sukmawati. 2003. Analisis Pengaruh Luas Pengungkapan 
Sosial Dalam Laporan Tahunan Perusahaan Terhadap Reaksi Investor (Studi Kasus Pada Perusahaan - Perusahaan High
Profile di BEJ). Jurnal Simposium Nasional Akuntansi VI, Surabaya. (16-17 Oktober).

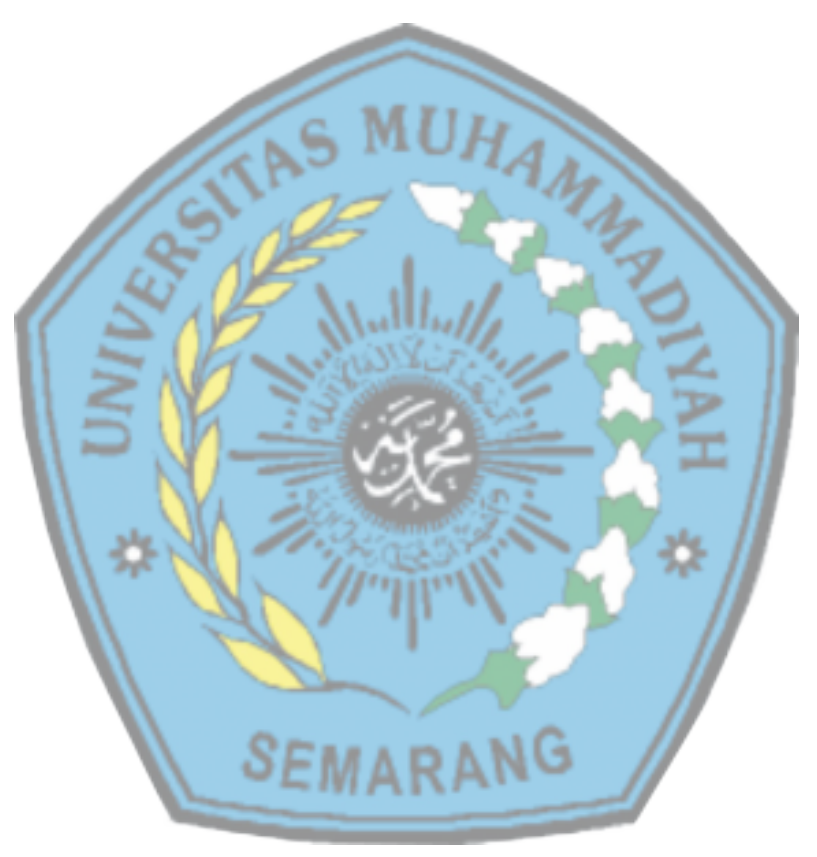

